\title{
EDITORIAL
}

\section{Quality Assurance of Research in Dental Education}

Recently there are 30 dental institutions in Indonesia which some of them are still managed by Faculty of Medicine. Each institution is trying to develop their education system to meet Quality Assurance (QA) guideline established by the government. Unfortunately the focus of development is restricted to teaching and learning activities, while the quality of research is still left behind. ${ }^{1}$ Hence the research development will increase competitiveness of institution and a good research can be used to solve some dental problems such as enhancement of dental services to community and development of dental instruments as well as dental material.

Research is a part of 'Tridharma Perguruan Tinggi' so each institution should commit to this activity and facilitate the faculty to do research as their contribution to knowledge and technology development. Involvement of undergraduate and postgraduate students in research activity may improve academic atmosphere, in the institution. The Act of Republic of Indonesia no 12, 2012 on Higher Education chapter 45 stated: Research in higher education is directed to develop knowledge and technology as well as to increase community welfare and nation competitiveness. ${ }^{2}$ In the globalization era this is the time for dental institutions in Indonesia to implement QA for research activity. QA should be conducted with the principal of never ending improvement, well planned and systematically review with clear time frame and quality achievement.

First step of QA is standard agreement/settlement. Regulation of Indonesian Medical Council no 22/ $\mathrm{KKI} / \mathrm{Kep} / \mathrm{XI} / 2006$ on Ratification of Dental Education Standard has stated the standard of research ${ }^{3}$ as follows: Standard of research quality comprises:

1. Quality of research per se
a. Clear research proposal/protocol
b. Qualified research team
c. Students involvement
d. Ethical clearance
e. National or international publication

2. Management of research quality, comprises:
a. Long, intermediate and short strategic plan.
b. Effective research organization
c. Research fund resources and management
d. Research facilities
e. Collaboration with other institution/organization
f. Research training, workshop and seminar

Research QA also includes method, system, and personnel who are responsible for transparency, process/procedure, handling of sample and research material, documentation and records.

In the university level there must be clear policy of research and management as stated in AUN QA Guidelines and Manual as follows: 'The University Research Policy sets the direction of research in the University. It specifies objectives of research in the university, research strategies, code of conduct for research, and responsibility of research management unit including research fund, research infrastructure, policies, procedures, standards and ethical practices of the university'.,

Faculty of Dentistry Universitas Indonesia (FKGUI) has started to re-organize research activities since the year of 2000 when the Faculty won the competition of Quality for undergraduate project ('Q' project) from Directorate of Higher Education Ministry of Education. FKGUI then had established Oral Biology laboratory, renovation of Library facilities and $\mathrm{PhD}$ scholarship programme for academic staffs. After more than ten years research activities in FKGUI have developed significantly, which can be seen from increasing number of research and sum of research fund. Some of students and academic staffs also get research awards from national as well as regional dental meeting.

Yet FKGUI must go on implementing standards of research to be recognized nationally and internationally. FKGUI should also make collaboration with other institution and support academic staffs and students to conduct research. Research collaboration amongst dental institutions may elevate the dental education in Indonesia and in the future may solve national problems such as dependency of dental material and instrument from abroad. Implementation of research standards is a challenge for FKGUI and other dental institutions which require ultimate commitment from the faculty and support from institution leader and management. Are we ready?

\section{REFERENCES:}

1. Peraturan Menteri Pendidikan Nasional no 63 tahun 2009 tentang Sistem Penjaminan Mutu Pendidikan. Indonesian.

2. Undang-Undang Republik Indonesia no 12 tahun 2012 tentang Pendidikan Tinggi, pasal 45. Indonesian. 
3. Standar Pendidikan Profesi Dokter Gigi. 2nd ed. Jakarta: Konsil Kedokteran Indonesia, 2008. Indonesian.

4. ASEAN University Network Quality Assurance Guidelines. AUN Secretariat. Bangkok-Thailand, 2004; p. 20.

5. ASEAN University Network Quality Assurance: Manual for the Implementation of the Guidelines. AUN Secretariat Bangkok-Thailand. 2006; p. 79 80.

\author{
Afi S. Sarsito \\ Chair \\ Indonesian Dental Council
}

